\title{
THE ROLE OF ISLAMIC CAPITAL MARKET FOR MICRO, SMALL, AND MEDIUM ENTERPRISES (MSMES) THROUGH SYNERGY OF MUTUAL FUND AND VENTURE CAPITAL INSTITUTION
}

\author{
Yulizar D. Sanrego ${ }^{1}$
}

\begin{abstract}
It is worldly known that one of the main obstacles which is often faced by the micro, small, and medium enterprises (MSMEs) practitioners is the ability to access sources of funding. At the time where the absorption of banking credit to MSMEs is still very limited, the role of sharia capital market is considered as an alternative to support this limitation. Expanding the role of sharia capital market finds it moment when Indonesia Finance Service Authority (FSA) issued regulations that provide space for the capital market to also active in real sector businesses. In accordance with the FSA Rules N0.37/2014, mutual fund (unit trust) in the form of Collective Investment Contract (CIC) - Limited Investment/ Participation Fund (LPF) has the objective to pave the way for mutual fund investors to make direct investments in real investments. The proposed model that might be realized to smoothen the intermediary role of sharia capital market to the development of MSMEs is through the hybrid model that might linking mutual fund/investment manager and corporate, particularly venture capital. Using Analytical Network Process (ANP) approach this paper indicates that with the value of rater agreement 1.0, the research found that there are four main cluster problems which become an obstacle the proposed model, namely: (a) the reputation of mutual fund/investment manager; (b) investment grade rating of corporate (venture capital); (c) risk appetiate of investor as shahib al-mal; and (d) government regulation. Policy recommendation that might become solution, according to the value of rater agreement 1.0 is sequentially as follow, namely: (a) fully support from government, especially for a relatively new mutual fund with no experience in the capital markets industry; (b) Corporate (venture capital) should be able to offer Islamic Microfinance Finance Institutions (IMFIs) and MSMEs that have good business feasibility to the mutual fund/investment manager as well as investor; (c) The government should be able to guarantee legal certainty in the context of protection, including advocacy for investors; and last but not least (d) There is an extremely hope that investors could change their investment behavior paradigm, from risk averse to risk taker.
\end{abstract}

Keywords: Sharia capital market, Mutual fund, Venture capital, MSME

JEL Classification: G1, G23, G24

Received: October 5, 2016; Revised: July 21, 2017; Accepted: August 25, 2017

1 University of Darussalam Gontor (UNIDA) Jl. Raya Siman Km. 6, Siman, Ponorogo, East Java Indonesia-63471. Email: senapatie@gmail.com 


\section{INTRODUCTION}

It is undeniable that Micro, Small, and Medium Enterprises (MSMEs) in Indonesia has a strategic role in development, including poverty alleviation. However, one of the main obstacles which is often faced by the MSMEs practitioners is the ability to access sources of funding. Hence, to get funding from the banks is not easy for them (unbankable). In general, the bank is difficult to tolerate the inherent risks MSMEs sector. Due of various shortcomings in contract enforcement and a poor information environment, formal financial institutions in a number of developing economies are overcautious about extending loans to individuals or firms, especially small and medium enterprises (SMEs) (Amidzic, Massara, \& Mialou, 2014).

According to the Ministry of Cooperative and Small Enterprises Medium data (2012), cooperatives and MSMEs accounted for over $99.99 \%$ of economic actors in Indonesia. This figure confirmed that the position and the role of MSMEs is very vital and real to accelerate and promote national economic growth including poverty alleviation. The number of MSMEs reached more than 57 million units and contributes to the employment of more than $97 \%$, or about 107 million people. This is indeed a national asset for sustainable economic development.

However, the great potential of MSMEs have not been fully well realized. The absorption of banking credit to MSMEs is still very limited. Some of MSMEs weaknesses remains as a constraint to obtain financial facilities from the banking industry. Therefore, the existence of alternative channels of financial services becomes relevant when the banking industry has not fully meet the demand of MSMEs. One potential source of funding for MSMEs is through the channel of capital market instruments issued by mutual funds.

In addition to conventional mutual funds that invest in the form of stocks, bonds, and money market instruments, there exist non-conventional mutual funds. There are various types of nonconventional mutual funds, including non-conventional mutual funds that invest in the real sector. If the conventional mutual fund invests in financial portfolios, non-conventional mutual funds might invest directly in the real sector. 
Mutual funds that invest in the real sector are categorized as Limited Investment/Participation Fund (LPF). The same legal form as conventional mutual funds, namely $\mathrm{CIC}$ (Collective Investment Contract) between the investment manager and custodian bank. LIMF activity is to raise funds by issuing share unit to the limited in number of investor. The collected fund are not only invested in various types of securities traded in the capital market and the money market, but could be channeled to finance specific projects in the real sector. In the context of financial inclusion, the role of this LIMF is significant for the distribution of financing for MSMEs from the capital market. With the experience of the large companies, investors through mutual funds can contribute to develop businesses in the real sector as well as to alleviate poverty. The idea of financial inclusion itself originated from a condition where some communities, particularly MSMEs, do not have the opportunity to obtain financing facility.

Providing financial services for MSMEs through money and capital markets is essential in order to develop businesses in the real sector. Once this MSMEs are growing well, it will naturally have an impact on the potential job creation which at the same time alleviating poverty. However the challenge is how financial markets, particularly sharia capital market, can assert its role in order to create and to develop the real sector economy by offering any instrument or business model which is meets the criteria of financial inclusion. It is well established opinion in finance theory that credit markets characterized by high asymmetric information, notably, the existence of moral hazard and adverse selection problems, leads to severe distortion and sometimes complete collapse of the formal credit market (Akerlof, 1970; Daripa, 2000 in Dusuki, 2008). Financial contracts will not be written under this condition.

However, as an investment instrument, the successful of LIMF is subject to the investor appetiate; whether they feel comfortable or not with this particular form of invetment. Investors will certainly look at critically what will be the underlying business behind the LIMF issuance. This paper, therefore, tries to highlight the proposed hybrid model of sharia capital market and venture capital that might be realized to smoothen the intermediary role of sharia capital market to the development of MSMEs as well as poverty alleviation. 
Hence, using Analytical Network Process (ANP) approach this paper try to analyze both problem and solution associated with the sharia Limited Participation Fund (SLPF) access for MSMEs in Indonesia

The remainder of the paper is organized as follows. Section 2 reviews the literatures regarding micro, small, and medium enterprises (MSMEs). Section 3 describes methodology in order to critically analyze the problem as well as the solution of the proposed model. Result and discussion are presented in Section 4. Finally, Section 5 contains conclusion and recommendation.

\section{LITERATURE REVIEW}

\subsection{Why MSMEs}

MSMEs are always seen as the main actors of economic development in many countries. Hence, the development of MSMEs would also increase the high level of employment rate as well as poverty alleviation. MSMEs are more labor-intensive and tend to lead to a more equitable distribution of income then larger enterprises. SMEs in developing countries and countries with economies in transition are regarded as the engine of economic growth; they face enormous challenges in attracting investors and accessing modern technology.

Empirical studies show that SMEs' contribute to over $55 \%$ of GDP and over $65 \%$ of total employment in high income countries, while they contribute over $95 \%$ of total employment and about $70 \%$ GDP in middle income countries. In the European Union countries, for example, there are some 25 million small businesses, constituting $99 \%$ of all businesses that employ almost 95 million people, providing $55 \%$ of total jobs in the private sector. Important contribution is also on exports and on productivity growth (OECD, 2004).

The World Bank's survey (2010) shows that only 47 percent of Indonesian households have access to formal institutions. This poor access is the result of low income, complicated bank operation, lack of financial and banking education, high bank administration fee, and far location of banks from people's houses. Therefore, there is a thought to apply financial inclusion strategy to boost economic 
activities of those who unable to make use financial services, there promoting equal income distribution and poverty reduction.

The same situation also happen to MSMEs. MSMEs which have a positive potential to the national economy still has no place in the financial industry. The role of MSMEs has proven to be national safety valve when the monetary crisis hit Indonesia in 1997-98. With its business character that is rooted in the real sector, MSMEs can offset the monetary crisis which is rooted in the monetary sector problems. If MSMEs are not empowered, it may lead to a greater poverty and burden the nation. In Indonesia total micro, small and medium enterprises (MSMEs) are 56,534,592 units (99.99\%), whereby large business only 4,968 units or only $0.01 \%$ out of total unit businesses. These MSMEs contribute significantly to the labor absorption with $97.16 \%$, while only $2.84 \%$ of them are absorbed by the large businesses Ministry of Cooperative and Small Enterprises Medium data (2012). Unfortunately, $60-70 \%$ of total MSMEs couldn't have any financial access to the formal financial institutions, particularly banking industry (LPPI, 2015).

This $60-70 \%$ figure of financing limitation is due of various shortcomings in contract enforcement and a poor information environment, formal financial institutions in a number of developing economies are overcautious about extending loans to individuals or firms, especially small and medium enterprises (SMEs) (Amidzic et al., 2014). Mostly borrowers or customers of microfinance that have several limitations: lack of working capital, low human resources, as well lack of knowledge and technology (Sudaryanto \& Hanim, 2002) are excluded from financial services.

The 2014 Global Financial Development Report (World Bank, 2014) identifies four major forms of financial exclusion, which are classified into voluntary and involuntary exclusion. From a macroeconomic perspective, the main objective for building an inclusive financial system should be, in principle, the minimization of the percentage of individuals and firms in group 4 of Figure 1.

Torre, Peria, and Schmukle (2010) highlighted three factors that make financial institutions uninterested in involvement with SMEs: 1) Financing SMEs is difficult because they are opaque, 2) SMEs are more likely to be informal compared with larger firms, 
something that compounds their opaqueness and poses additional obstacles and risks to SMEs lending, and 3) Banks cannot lend to SMEs if they are unable to provide reliable accounts stealing their financial activity. Hence, lending to SMEs is considered as a high risk and unprofitable business due to unavailability of accurate and reliable information on the financial condition and performance of the enterprises, unconvinced and weak business plan, and weakness in management and information technology. In addition, bank also has weaknesses in identifying characteristics of SMEs, availability of other profitable investment to banks, higher overhead cost to the bank due to a high number of customers with smaller loan size, and higher interest rate on the loans from the informal lending market (Rudjito, 2003).

Simply put, there are several factors that obstruct the public to access the financial sector formally. Those factors can be categorized into two: demand side and supply side. From demand side, access is hindered because of the lack of knowledge and public awareness of the financial services, low income, and lack of guarantee and socially inclusive. From the supply side, several factors that often makes people cannot access the formal financial sector such as the distance from the bank branches from the house, complicated procedure, a mismatch of financial products to the needs, language barriers, the officer manner, and the rigid operating hours of the bank (Rakhmindyarto \& Syaifullah, 2014).

Instead of having the issue of financial exclusion, MSMEs is still considered as an engine of economic growth, increase the high level of employment rate as well as poverty alleviation. MSMEs can bypass traditional bank lending by instead issuing equity and debt securities in the capital markets (Calvey, Romeo, \& Peterhoff, 2014). Therefore, any efforts or alternative channels to provide financial services for them are very much awaiting including sharia capital market. The role of sharia capital market that might channel their fund to MSMEs will support financial inclusion policy put forwarded by government accordingly. 


\subsection{The Role of Sharia Limited Participation Fund (SLPF)}

At the time where the absorption of banking credit to MSMEs is still very limited, the role of mutual fund feels very important to support this limitation. Expanding the role of sharia capital market to improve businesses in the real sector finds it moment when Indonesia Finance Service Authority (FSA) issued regulations that provide space for the capital market to also active in real sector businesses. Hence, Chief Commissioner Boards of Finance Authority Service (FSA) Indonesia has asserted that the contribution of financial services sector will be focusing on how to create equity as well as national prosperity. His statement made clear once FSA established seven strategic initiatives, which one of them is enhancing the role of capital market as a long term sources of financing (Haddad, 2017).

In accordance with the FSA Rules N0.37/2014, mutual fund (unit trust) in the form of collective investment contract (CIC) Limited Investment/Participation Fund (LPF) has the objective to pave the way for mutual fund investors to make direct investments in real investments such as project development, investment to the non-go public corporation, and so on. It means, this LPF could be an alternative for MSMEs and entrepreneurship as a source of funding.

As a matter of regulation, LPF investment on certain project could be in the form of purchasing debt securities (medium term notes, promissory notes, or bonds), direct investment in shares, or direct investment to buy land and buildings. While in the sharia capital market, Sharia Limited Participation Fund (SLPF) investment could be any form of projects (including MSMEs), Islamic bonds (sukuk) excluding securities which is subject to the existence of any form of interest. In this case, the provision of income to investors is interest-free based on debentures, instead according to what type of sukuk issued by issuers that doing a project or business in the real sector. Any form of sukuk issued will be the underlying reason for the sukuk holder to earn income, which is very much difference from that of interest-based income as being practice in conventional capital market. Thus, SLPF sold in the form of units by investment manager/mutual fund could be the intermediary institution for MSMEs to obtain funding from the sharia capital market. 


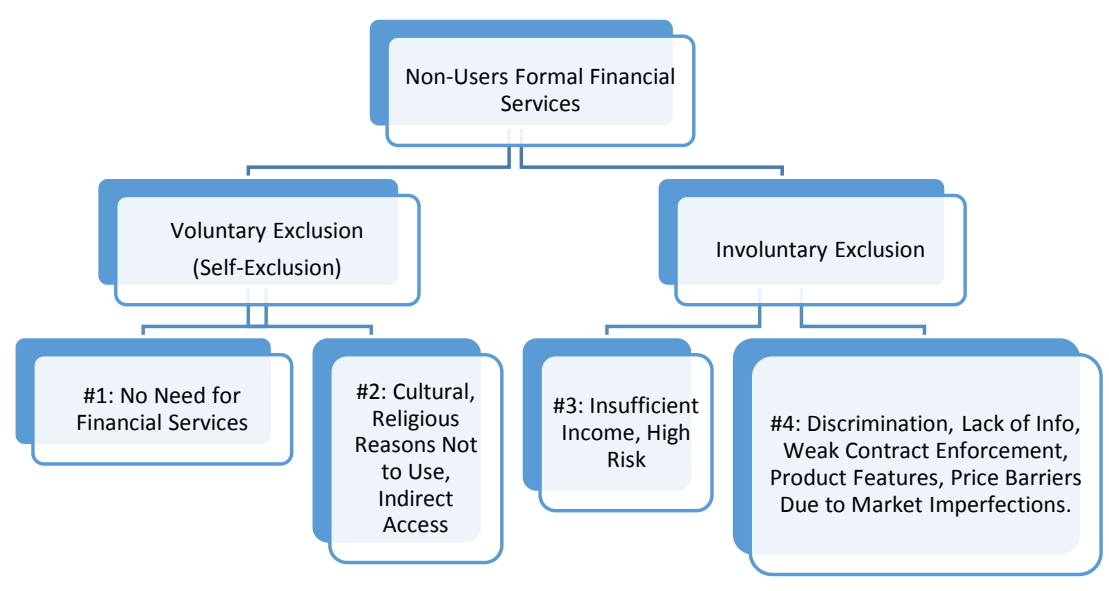

Figure 1.

Financial Exclusion

Source: Adapted from World Bank (2014)

Collective Investment Contract $(\mathrm{ClC})$ is a contract between investment manager (mutual fund) and custodian bank that binds unitholders in which investment manager is authorized to manage the collective investment portfolio (LPF) and custodian bank is authorized to carry out collective custody (Sitompul, 2000). Mutual fund products inthe form of Collective Investment Contract (CIC) Limited Investment/Participation Fund (LPF) that has been issued by Bapepam-LK (Finance Authority Service) No. IV.C.5 similar to Private Equaty Fund (PEF); it is a product of mutual fund which is directly invested into the real sector. Investment manageer through PEF collect funds from investors to inancing projects in the real sector, such as infrastructure. Burg and Rasmussen (2007) defines PEF as a means that is used to collect funds from a number of investors to be invested either in equities or equity-related securities of a company which in general are not listed on the Stock Exchange (close). PEF can be a corporation or limited partnership.

Limited Participation Fund (LPF) globally known as Private Equity Fund (PEF). What distinguishes LPF with PEF is LPF can only invest in instruments issued by companies that are not offered through initial public offering (IPO). This means that the investment is made in closed-companies that have not initial public offering (IPO), while overseas PEF may invest in open and closed-companies. 
Compare to conventional mutual fund, LPF Mutual Fund are not limited to the capital market intsrument and securities but can also be direct investments in real sector projects.

Any efforts which is direct Sharia capital market as an intermediary institution for MSMEs to obtain funding is in line with government policy related to the financial inclusion vision that aims to open up space for financial sector to alleviate poverty. There is a hope that any financial services both in money market or capital market, not just dwell on how financial institutions raise funds but also how these funds could be well distributed to the public (especially MSMEs) and well utilized in their business activities in order to grow and develop which is at the same time reduce poverty. Financial inclusion can be broadly defined as an economic state where individuals and firms are not denied access to basic financial services based on motivations other than efficiency criteria (Amidzic et al., 2014).

Financial inclusion is a correction to the financial exclusion; whereby it is a financial condition that only benefits a particular party only. Another definition of financial inclusion according to the World Bank (2010) and European Commission (2008) is a comprehensive activity that aims to eliminate all forms of barriers both in price and non-price forms to the public access in using or utilizing financial services.

With regard to the potential role of capital market to support MSMEs fund, Calvey et al. (2014) initiated that capital market solutions available to SMEs can be divides into three broad categories: (a) SME Equity Platforms; (b) SME Debt Platforms; and (c) Alternative Listing Venues (without trading). The first two models will be out of discussion in this paper, since from the typical SMEs' lifecycle stage both of categories are need established or mature companies. However, instead of having platforms within the third model that facilitate the lending process between borrowers and investors through peer to peer (P2P), peer to business (P2B), investor to peer (B2P) or investor to business (B2B) transactions, the proposed model in this paper will come up with the hybrid model linking capital market and venture capital. 


\subsection{The Proposed Model and Why Venture Capital?}

With all the limitations inherent in MSMEs in the form of lack of working capital, low human resources, as well as lack of knowledge and technology (Sudaryanto \& Hanim, 2002), optimization of Sharia Limited Participation Fund (SLPF) can be utilized through the role of medium or large corporations which can issue sukuk (corporate sukuk). This matured corporate will facilitate MSMEs to potentially get funds to improve their businesses/corporate in the form of venture capital, SLPF fund could be channeled to MSMEs to through a network of Islamic Micro Finance Institutions (IMFI).

Venture capital is one source of non-bank financing, which is quite prevalent in developed financial market for small or start up firms (Keuschnigg, 1998). Venture capital generally have a network of like-minded investments and this proves useful for networking and forming strategic relationships/partnerships, particularly with that of microfinance institutions. Within network and relationship perspective, some venture capitals presumably have better-quality relationships and hence enjoy more influential networks positions than others, impying differences in clout, investment opportunity sets, access to information, etc (Hochberg, Ljungqvist, \& Lu, 2007). In other words, non-bank financial institutions such as venture capital could manage themself as a parent company in the process of issuing sukuk to be channeled to MSMEs through microfinance institutions. By doing so, the role sharia capital market as intermediary institution will be increased to cover the limitations of banking industry in financing MSMEs.

As being practiced by one of the prominent venture capital in Indonesia, PBMT Venture Capital. This Venture Capital established by some of Islamic microfinance institutions (Baitul Mal Wa Tamwill BMT) with strong network and relationship. These Islamic microfinance institutions share their equity to establish PBMT Venture Capital and having various businesses, including Micro, Small, and Medium Enterprises (MSMEs). At the end of the day, once these businesses generate income; the income goes to Islamic microfinace to support their growth and sustainability. The vision of this particular Venture Capital model is Being the main player in financial services for micro, small and medium enterprises through the BMT network, as well as be a benchmark and model of success for Islamic 
microfinance institutions development (PBMT Ventura, 2016). The economic impact of venture capital has been realized by MSMEs in sales growth, profit, asset, and improvement in management of finance and other resources. The social impact from venture capital perspective include the employment opportunities created which has improved people's lives and alleviated poverty among the employes (Memba et al., 2012).

One of the major reasons why the financial assistance or service for MSMEs should be handled by venture capital is that, they are doing managerial assistance as well as monitoring their business partner (Fuady, 2006). Hence, as being stated by Chief Commissioner Boards of Finance Authority Service (FSA) - Indonesia during National Seminar 2015, the existing system of venture capital industry is very suitable to enhance the role of MSMEs through financing programs other than those offered by banking system. Especially for the MSMEs that are newly started. Financing of venture capital is not only targeting to the new entrepreneurs, but also should lead to some sectors that have high potential growth.

As long as the potential funding from SLPF product and the significance role of venture capital concern, the hybrid model of sharia capital market and venture capital that can be proposed in order to enhance MSMEs business is as depicted at Figure 2. The operasional mechanism of the SLPF and venture capital using sukuk mudharabah is as follow:

1. The contract between investor and investmen manager might be used wakalah,

2. The contract between investment manager and investment fund user (venture capital) might be used mudharabah, and

3. Since MSMEs having high risk, the contract between venture capital and Islamic microfinance might be used mudharabah muqayyadah (restricted mudharabah).

The character of mudharabah contract is as follow:

1. Benefit sharing between investors (shahib al-mal also as muwakkil), represented by investment manager (wakil) and investment fund user based on the proportion that has been agreed upon and there is no guarantee of a particular income to the investors. 
2. Shahib al-mal only bear the risk of the funds that have been given.

3. Investment Manager as wakil does not bear the risk of losses on its investments along not because of negligence (gross negligence/tafrith).

However, apart from this sukuk mudharahah scheme, the parties might agree upon other schemes that might well fit with their risk appetites or interest, such as sukuk ijarah, sukuk murabahah, or even sukuk waqf.

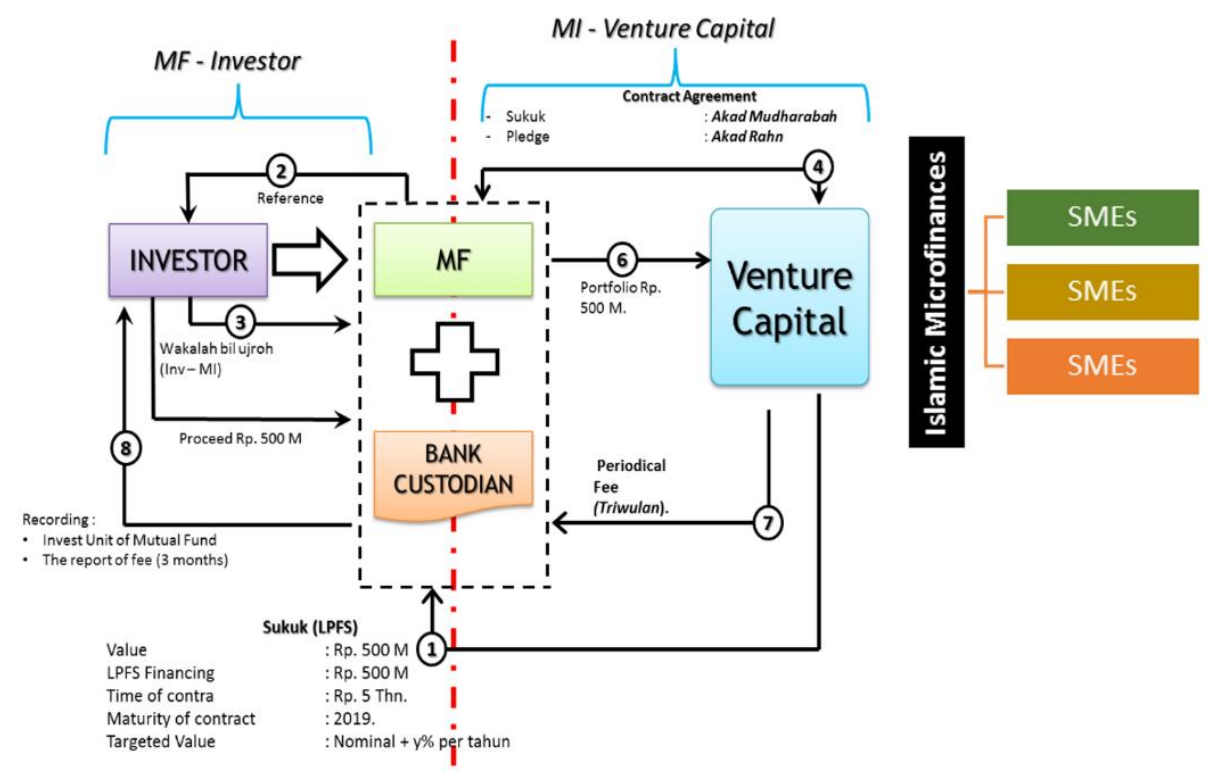

Figure 2.

Hybrid Model of Sharia Mutual Fund \& Venture Capital

Source: Adapted from PBMT Venture Capital with modification

However, as a matter of fact, there exist the problem of Sharia Limited Participation Fund (LPF) access for MSMEs in Indonesia through the model depicted at Figure 2. It is therefore, this paper trying to come up with the exploration of what short of problem and solution that might happened in this proposed model. 


\section{RESEARCH METHODOLOGY}

This study is a qualitative-quantitative analysis which aims to capture the value or views that represented by the experts and the practitioners on the problem of Limited Participation Fund (LPF) access for SMEs in Indonesia. Qualitative is a process to understand the natural problems from complexity description, through reported information from respondents views and conducted in natural condition (Sugiyono, 2005).

While quantitative study is a process of decision making based on data (Kuncoro, 2004). This study combined between qualitative approach that capture the respondent's views and quantitative approach. The most suitable method used for this study is Analytic Network Process (ANP).

This study uses data several interviews and analysis of literature studies on the problem of Sharia Limited Participation Fund (SLPF) access for MSMEs in Indonesia. ANP method is employed in this study by collecting the data and information preferences/ comments/opinions that are represented by experts and practitioners in Sharia capital market industry. To obtain these data, the authors used questionnaires/interviews to the experts and practitioners. It is helpful method in assisting the mind to organize its thoughts and experiences and to elicit judgments recorded in memory and quantify them in the form of priorities, and allow for representing diverse opinions after discussion and debate (Saaty \& Vargas, 2006).

\subsection{Data Collection Techniques}

In conducting research using ANP, there are two stages of data collection. The first stage is data collection by in-depth interview with some experts and practitioners related to the problem of Limited Participation Fund (LPF) access for SMEs in Indonesia who will become the respondents. The interview is to obtain in-depth information about the problem and to create ANP framework.

Second stage is composed ANP framework to design questionnaires according the framework that has been created. Questionnaires will be distributed to the respondents accordingly. 
These questionnaires are needed to perform measurement using a ratio scale.

There are two ways in collecting data. First, by Focus Group Discussion (FGD) in which the respondents were gathered in one forum and do a deal to the questions on the questionnaires. The second way is to conduct in-depth interviews in which experts and practitioners are interviewed separately. In this study, the second way is more likely to be done.

\subsection{Data Analysis Techniques}

Data analysis in ANP is used "Super Decisions". When the data has been collected and the result of questionnaires in ANP framework has been done, the next step is processing data by Super Decisions. Super Decisions is a tool used to make decisions by dependent feedback. This tool is used to implement AHP and ANP methodology. Both are used to find priority scale in each cluster.

\subsection{Method}

\subsubsection{General Description of ANP}

According to Saaty (2005) ANP is "a multicriteria theory of measurement used to derive relative priority scales of absolute numbers from individual judgments (or from actual measurements normalized to a relative form) that also belong to a fundamental scale of absolute numbers. These judgments represent the relative influence, of one of two elements over the other in a pairwise comparison process on a third element in the system, with respect to an underlying control criterion".

This method is a new method that comes from further AHP (Analytic Hierarchy Process) development. The superiority of ANP from another methodology is its ability to measure the synthesis of a number of factors in the hierarchy or network. The fundamental difference between ANP and AHP is on the hierarchical assumption of independent elements of higher to lower elements. While in the ANP, the relationship between elements based on network without levels (Saaty, 2005). In the hierarchical patterns did not reveal any feedback from elements of high to lower elements. In hierarchical also did not reveal any elements that can affect itself. On the other 
hand, in the network pattern, there is relationship between cluster and its can be reciprocal links either directly or indirectly through intermediaries cluster (Bu-Qammaz, 2007). For more detail can be seen on the figure below:
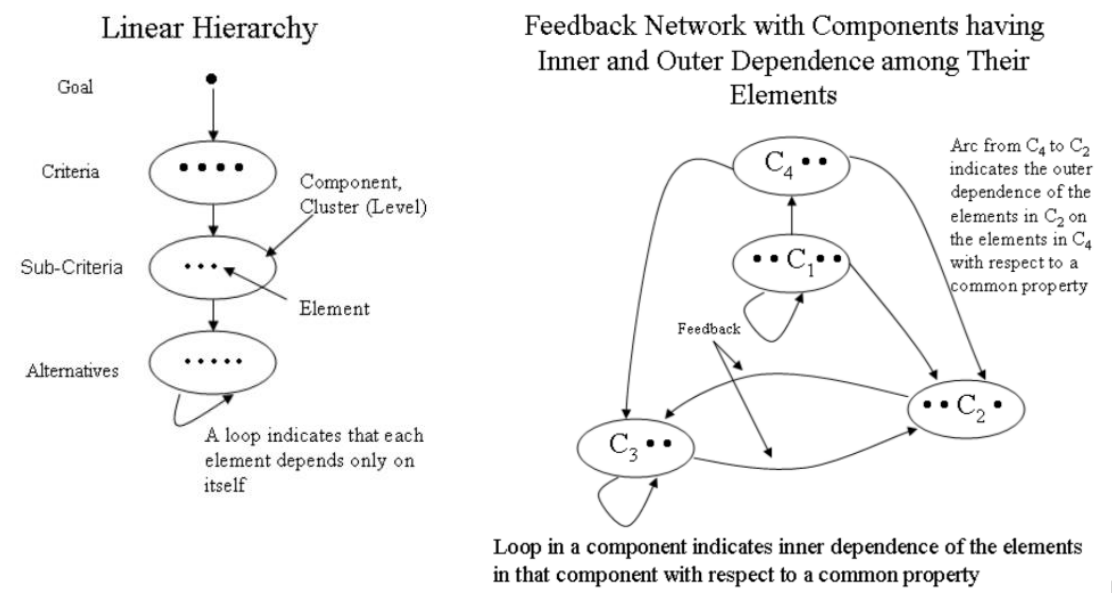

Figure 3.

The difference Hierarchical Pattern and Network Pattern (Saaty, 2005)

ANP is designed in order to know the overall effect of all the elements. Therefore, all criteria must be set up and made a priority within the framework of the control hierarchy or network, make comparisons and synthesis to obtain a set of priority. Then we derive influence of the elements in the feedback system with attention to each criterion. Finally, the results of this effect are weighted by the importance of the criteria and are added to obtain the overall influence of each element.

\subsubsection{Axioms in AHPIANP}

Every theory based on axioms. According to Saaty and Vargas (2006) there are four axioms in AHP and ANP:

1. A priority or weight, which is an absolute number, belongs to the closed interval $(0,1)$ and is a measure of relative dominance.

2. Reciprocal. If there are not actual measurement of objects, then judgments are expressed in the form of comparison between 
two objects. If object $A$ is three times biggger than object $B$ ( $A$ $=3 B)$, then object $B$ is three times smaller than object $A(B=1 / 3$ A).

3. Homogeneity. If the objects are homogeneous and if respondents have knowledge and experience, paired comparison actually derive measurements that are likely to be closed and that indicate magnitude on an absolute scale. Homogeneity is the motivation for the 1-9 evaluation scale. The upper limit of 9 is generates due to the requirement of homogeneity to maintain the stability of the eigenvector to pertubation from consistency, and also to the requirement that only a small number of elemenets should be compared (see Table 1).

4. A dependence condition is assumed that system can be decomposed into component parts. Both the scale and the number of elements compared can be extended indefinitely.

Table 1.

The Fundamental Scale of Absolute Numbers

\begin{tabular}{|c|c|c|}
\hline Definition & $\begin{array}{l}\text { Intensity of } \\
\text { importance }\end{array}$ & Explanation \\
\hline Extreme importance & 9 & \multirow{2}{*}{$\begin{array}{l}\text { The evidence favoring one } \\
\text { activity over another is of the } \\
\text { highest possible order of } \\
\text { affirmation }\end{array}$} \\
\hline $\begin{array}{l}\text { For compromises between the } \\
\text { above values }\end{array}$ & 8 & \\
\hline $\begin{array}{l}\text { Very Strong and Demonstrated } \\
\text { Importance }\end{array}$ & 7 & \multirow{2}{*}{$\begin{array}{l}\text { An activity is favored very } \\
\text { strongly over another, its } \\
\text { dominance demonstrated in } \\
\text { practice }\end{array}$} \\
\hline $\begin{array}{l}\text { For compromises between the } \\
\text { above values }\end{array}$ & 6 & \\
\hline Strong Importance & 5 & \multirow{2}{*}{$\begin{array}{l}\text { Experience and judgment } \\
\text { strongly favor one activity over } \\
\text { another }\end{array}$} \\
\hline $\begin{array}{l}\text { For compromises between the } \\
\text { above values }\end{array}$ & 4 & \\
\hline Moderate Importance & 3 & \multirow{3}{*}{$\begin{array}{l}\text { Experience and judgment slightly } \\
\text { favor one activity over another } \\
\text { Two activities contribute equally } \\
\text { to the objective }\end{array}$} \\
\hline $\begin{array}{l}\text { For compromises between the } \\
\text { above values }\end{array}$ & 2 & \\
\hline Equal Importance & 1 & \\
\hline
\end{tabular}

Source and adopted: Saaty, 2005

\subsubsection{Steps of ANP}

There are at least three main steps within the framework of ANP, that is: 1. Decomposition; 2. Pairwise comparison; and 3. Synthesis and analysis. The overview of these steps are as follow: 
1. Decomposition. The problem in this reserach is decomposed through more organized structures to serve understanding of the complexity of the problem (Saaty \& Vargas, 2006). Through a decomposition, problems are structured as network which include clusters, elements, and dependence among clusters and elements (see Figure 5).

2. Pairwise comparison. The process of comparison is a way of giving meaning to objects by relating them to the goals through prioritization, ordering, and classification. The ANP provides a scientific way to use comparisons through measurement for a decision which is structured as a network with dependence and feedback. When comparing two objects, smaller objects are used as a unit, and larger objects are estimated as a multiple of smaller unit. Priorities are obtained by synthesizing different sets of pairwise comparisons (Saaty, 2005).

3. Synthesize and analysis. There is no any method that has synthesis facility as provided by AHPIANP (Ascarya, 2005). For this step consist of four main issues, that is: a) consistency, b) rater agreement, 3) the group judgment, and d) obtaining priorities. The overview of each issues are as follow.

\section{a. Consistency}

The issue of inconsistency for a judgment matrix can be computed as a function of its maximum eigenvalue $\lambda_{\max }$ and the order $n$ of the matrix. A positive reciprocal matrix $A$ has $\lambda_{\max } \geq n$ with equality if and only of $A$ is consistent. Consistency index is a measure of deviation from consistency of A, denoted by $\mu$ (Saaty, 2005).

$\mu=\frac{\lambda_{\max }-n}{n-1}$

Where $\mu=$ consistency index; $\lambda_{\max }=$ maximum eigenvalue of matrix $\mathrm{A}$; and $n=$ order of matrix $\mathrm{A}$.

\section{b. Rater agreement}

It is a measure of the agreemnt among several judges in assessing on elements in one cluster. One of the tools to measure rater agreement among several judges who are assessing a given set of $\mathrm{n}$ objects in Kendall's coefficient of 
concordance (W). Depending on the application field, the judges can be variables, characters, and so on. In ANP, judges refers to respondents, which are experts in the area being studied. Kendall's W statistic, where $0 \leq \mathrm{W} \leq 1$; W $=1$ occurs when all respondents are in total agreement (Legendre, 2005).

\section{c. The group judgment}

The issue relating to group decision making is how to aggregate individual judgments to construct the judgment of the group. If the individual respondents have different priorities of importance, then geometric mean is formed to represent the group judgment (Saaty, 2005).

$$
G M k=\sqrt[n]{(R 1 * R 2 * \ldots * R n)}
$$

Where $G M=$ Geometric Mean; $R=$ judgment of individual respondent; $n=$ number of respondents; $k=$ number of pairwaise comparisons.

\section{d. Obtaining priorities}

The final step in ANP is how to synthesize all possible alternatives to obtain overall priorities. To obtain priorities among alternatives, one need to derive the priority vectors, which are the principal eigenvector of the pairwise comparison matrices. The rank of priorities could be captured from the ordering the value of principal eigenvector of those matrices (Saaty, 2005).

\section{RESULT AND ANALYSIS}

\subsection{Decomposition of Problem}

Of the few opinions that have been collected from experts through in-depth interviews (depth interview), there are some problems that still hamper the funding of MSMEs through Sharia Limited Participation Fund (LPF) in Indonesia. Some problem in this particular matter could be critically look at the four main issues: (a) mutual fund/investment manager; (b) as Islamic bond or sukuk issuers; (c) investors as shahib al-mal; and (d) government regulation. The 
conceptual framework outline of the decomposition network can be depicted at the following Figure 4:

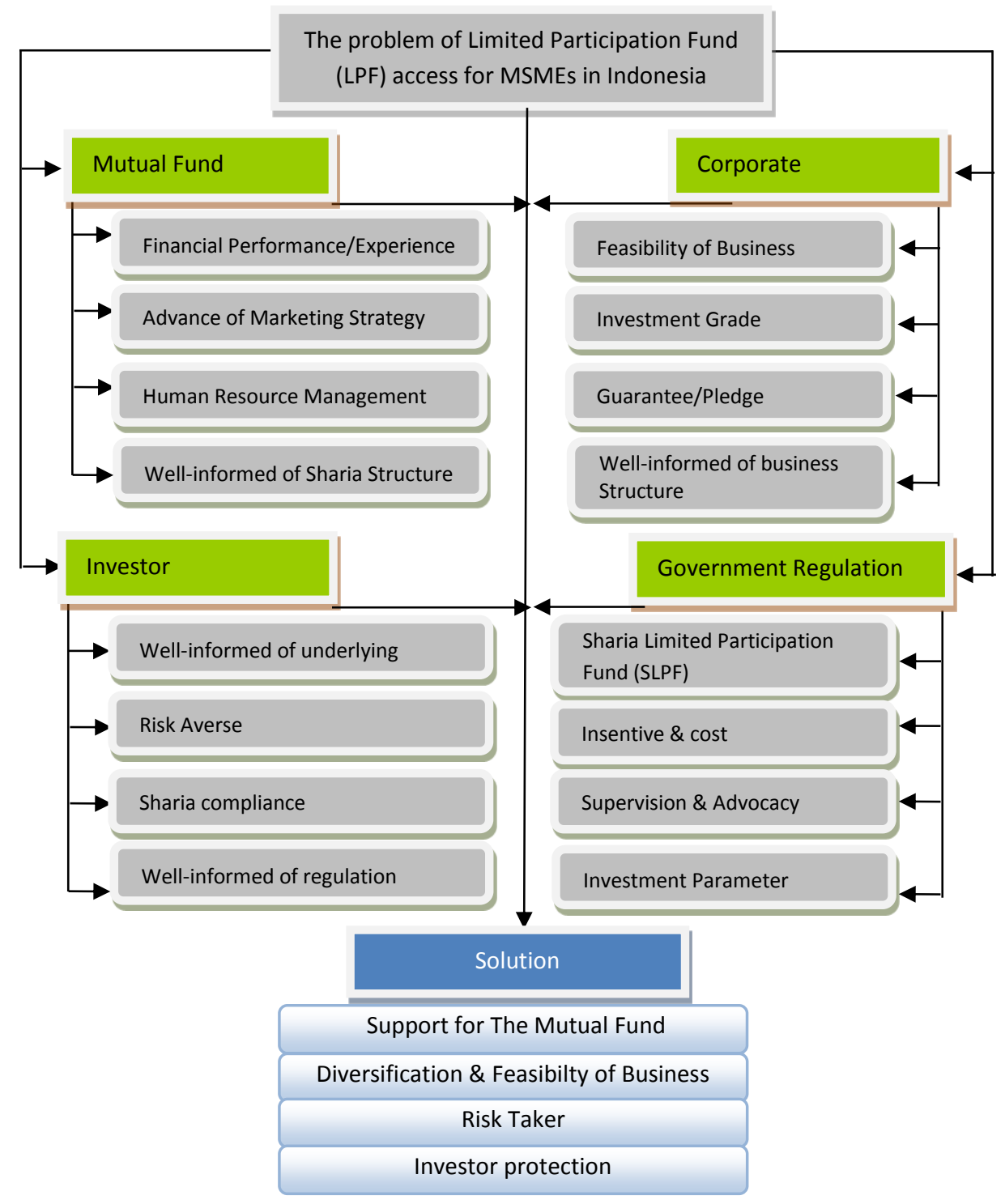

Figure 4. Problem Decomposition 
100 The Role of Islamic Capital Market for Micro, Small, and Medium Enterprises (MSMEs) Through Synergy of Mutual Fund and Venture Capital Institution

\subsection{Priority Comparison Analysis}

\subsubsection{The Analysis and Result of General Problem (Clusters)}

Decomposition of the problem is an important stage in studies using ANP method. Decomposition problem is made in super decision format, so that getting questionnaire format. Having fulfilled the questionnaire from the respondents, the next step is putting this questionnaire into a super decision software to get the value of geometric mean which is depicted in the following figures:

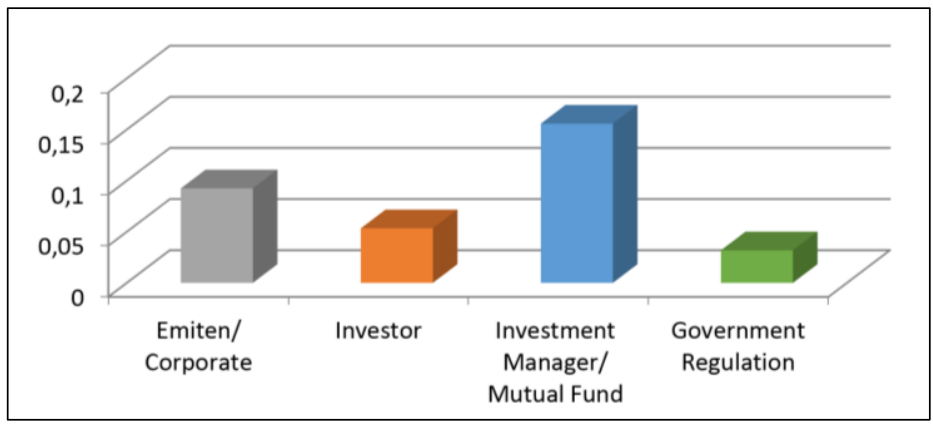

Figure 5.

Priority Level of General Problem

Figure 5 shows that investment manager/mutual fund is the main problem in the issue of access limitation of Sharia Limited Participation Fund (SLPF) for MSMEs in Indonesia with its priority scale 0.15 . In this context mutual funds have less experience or reputation in the capital markets industry, despite having a good performance from the financial side. Angel investors of SLPF, usually, very concerned about the reputation and the background of mutual fund/investment manager. Reputation of the firm is one of determinant that influenceindividual investment decision (Jagongo \& Mutswenje, 2014). It is difficult for the newly started mutual fund to have a trust from the investor (shahib al-mal) to get their investment fund. Following after mutual fund/investment manager with their value of priority scale are: corporate (0.08), investor (0.04), and government regulations (0.02). In line with the reputation reason, it is siginificance from the perspective of investor to ascertain that corporate is feasible to generate income/earning (Jagongo \& Mutswenje, 2014). 
Rater agreement (degree of agreement) 1.0. indicates that all the respondents (experts) has the same opinion with regard to this priority level of problem why SLPF couldn't really work as source of fund for MSMEs. However, it doesn't mean that this priority level of problem neglecting other than mutual fund/investmen manager as the whole general problem. Rather, those the four issues above are simultaneously have a significant role as a determinat factor of why SLPF couldn't really work as source of fund for MSMEs in Indonesia.

\subsubsection{The Result of Detailed Clusters}

In this section, the detailed problem from each of the four main cluster problems will be provided with regard to the problem of Limited Participation Fund (LPF) access for MSMEs in Indonesia, according to the indepth-interview analysis. The details are as follows:

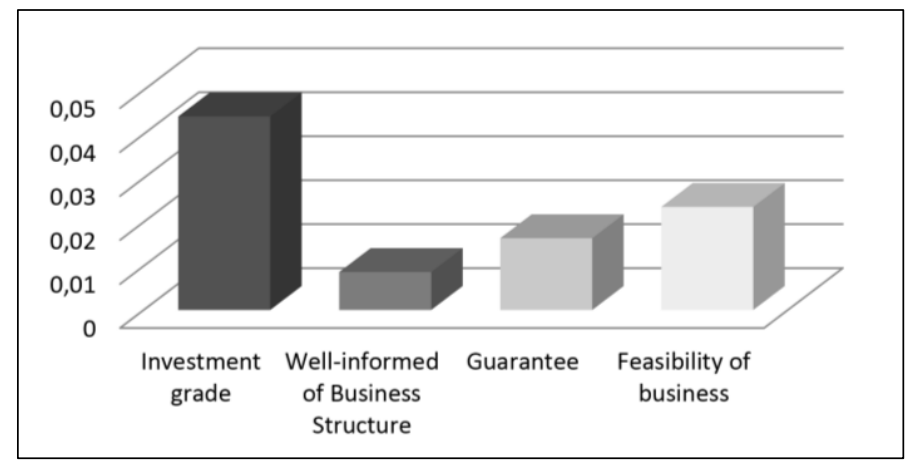

Figure 6.

Priority Level of Corporate Problem

Respondents agreed that some of the problems that are common among corporate to have an access to SLPF comprised of four main issues, namely: (a) investment grade; (b) well-informed of business structure; (c) guarantee or the availibility of the pledge; and (d) feasibility of business. In the context of investment grade which is engaged in the MSMEs sector often have difficulty in the rating process. Current rating agencies are more likely using profit-oriented parameter to do the rating process upon corporate business. The global issue of Sustainable Development Goals (SDGs) within the framework of triple bootom line (profit, people, and planet) might 
become a newly concept to formulate rating parameters. Alliging financial market development with sustainability outcomes, including: increasing access to sustainable finance for low-income communities as as micro, small, and medium-sized enterprises (UNEP Inquiry, 2016). Therefore, rating agencies should go beyond traditional parameter that might also include the triple bottom line framework in their rating process.

Another challenge for corporate is the extent to understand the whole process to be followed when dealing with capital markets industry. It often happens, the issuer is not ready with the documents that have an impact on the relative time in the process of issuing bonds (sukuk).

The availability of guarantee or pledge is another issue that must be ensured in the process of issuing bonds (sukuk). As a matter of sharia compliance, this point is being one of differentiator with securities practiced in conventional capital markets. In the sharia capital market practice, the availability of underlying asset becomes absolutely necessary in order to ensure the issue sharia compliance. Last but least, or corporate must be assured that the proposed MSMEs business is feasible. In fact, angel or sophistecated investors are very sensitive to the issue of business feasibility. In other words, business feasibility become as one determinant factor for angel investors whether to invest their fund in SLPF or not.

Of the four issues related to corporate problem cluster, all the respondents are at the same view that the most sensitive problem in the sales process of SLPF is the corporate must have good invetment grade, successively thereafter feasibility of business, the existence of pledge, and the readiness of the corporate to ensure that the entire document truly prepared in accordance with the usual procedures in the capital markets industry. The same view of all the respondents is reflected by the value of 1.0 rater agreement. 


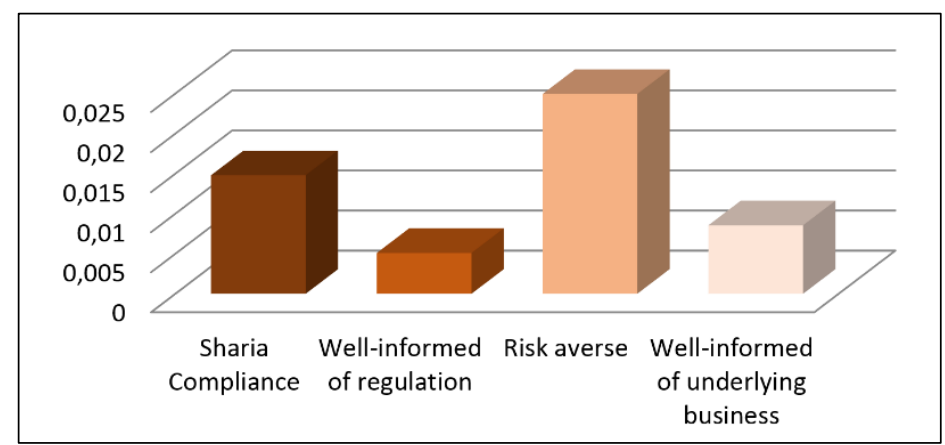

Figure 7.

Priority Level of Investor Problem

Figure 7 indicates that all the expert respondets prioritizing the problem of risk averse of the investor compared to other issues. In the context of investment behavior of investors confirmed that the problem of Limited Participation Fund (LPF) access for SMEs in Indonesia is often caused by the risk investors' appetite. Investors often do not want to face a high risk, knowing that their funds will be allocated to the MSMEs sector which does have a high risk. However, if the investors are willing to take risks to allocate their funds to the MSMEs sector, it would have the potential to improve the economics of the real sector, increase employment rate, including poverty alleviation (Memba et al., 2012). Following after risk averse with their value of priority scale are: sharia compliance (0.03), underlying business (0.007), and well-informed of regulation (0.0008). Rater agreement resulting from the data processing of the fourth problems mentioned above demonstrates 1.0. This means that the experts have the same view and agreed related to the level of priority of the four problems that are common in the investor behavior. 


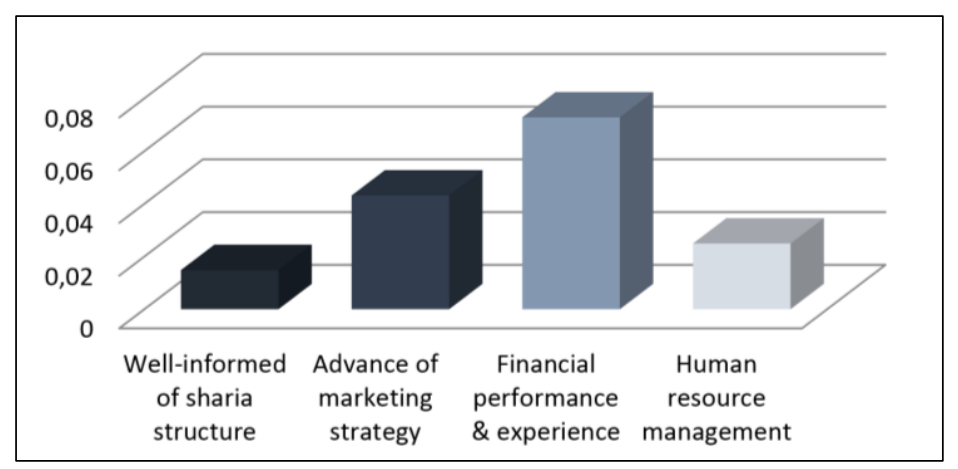

Figure 8.

Priority Level of Mutual Fund Problem

Based on the geometric mean values, it can be concluded that the expert respondents prioritize financial performance and experience of mutual fund/investment manager at the top priority level that often causes the problem of Limited Participation Fund (LPF) access for MSMEs in Indonesia occurred. Corporate with relatively good financial performance and its business, become lessattractive if mutual fund/investment manager as its partner does not have a good reputation in the capital markets industry. In this context it should also presumably that corporate as sukuk issuer (for instance) employ mutual fund/investment manager as they partner who has a good reputation in the capital market industry in order to obtain funds for financing MSMEs. Following after the reputation of mutual fund that is causing the problem of Limited Participation Fund (LPF) access for MSMEs in Indonesia is the advance of marketing strategy, human resource management, and well informed of sharia structure. The issue advance of marketing strategy, in particular, is closely linked to the reputation of mutual fund. Mutual fund with poor reputation, could be assisted by the marketing strategy advance of the mutual fund/investment manager to attract angel investors. With the value rater agreement 1.0, it is enough to indicate that the expert respondents has the same view and agreed related to the level of priority of the four problems that are common in mutual fund/investment manager institutions. 


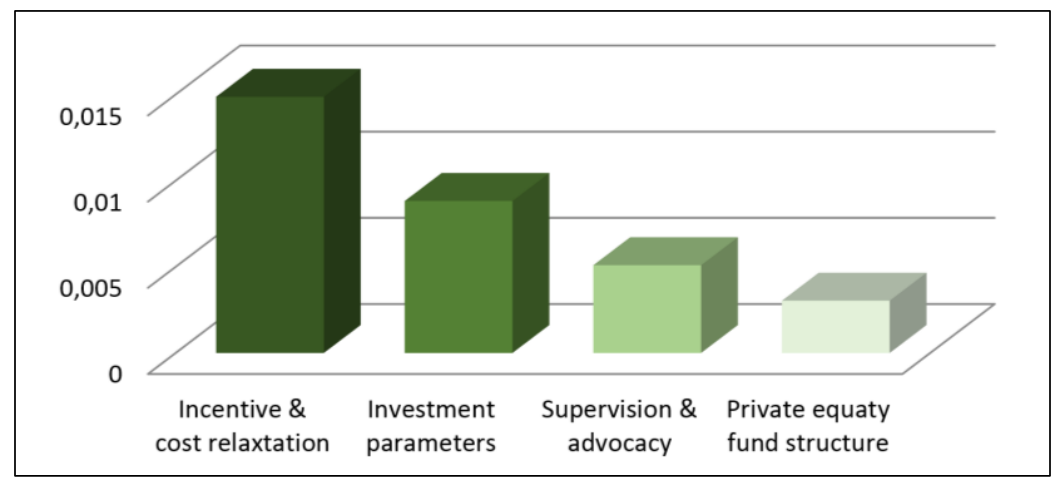

Figure 9.

Priority Level of Government Regulation

The value of rater agreement in the Government Regulation cluster is 1.0. It is indicates that there is a common view of experts that four of the above problems are caused the problem of Limited Participation Fund (LPF) access for MSMEs in Indonesia occurred.

According the Figure 9 related to the priority level in government regulation cluster problem, the expert respondents viewed that incentive and cost relaxation as the first priority which leds to the problem of Limited Participation Fund (LPF) access for MSMEs in Indonesia. Some costs that could be potentially arised both sides of the corporate which engaged in the real sector and the mutual fund/investment manager might become a burden for both parties. Therefore, reducing the cost of regulatory compliance costs for the proposed hybrid model is critical for encouraging MSMEs (Calvey et al., 2014). Following sequentially after the costs problem with their level of priority are investment grade parameters, supervision and advocacy as well as limited participation fund or private equity fund structure. In the context of investment grade parameters, the government should ask rating agencies to have rating parameter which is not mainly base on profit oriented, but also must has rating parameter base on social impact.

The whole detailed explanation of each four main cluster problem could be looked at Figure 10. The gray colour of the diagram is belong to the detailed problems associated with corporate. The red diagram is the detailed problems of the investor as shahib al-mal. The blue diagram is the detailed problems of the 
mutual fund/investment manager. While the green one is the detailed problems associated with government regulations.

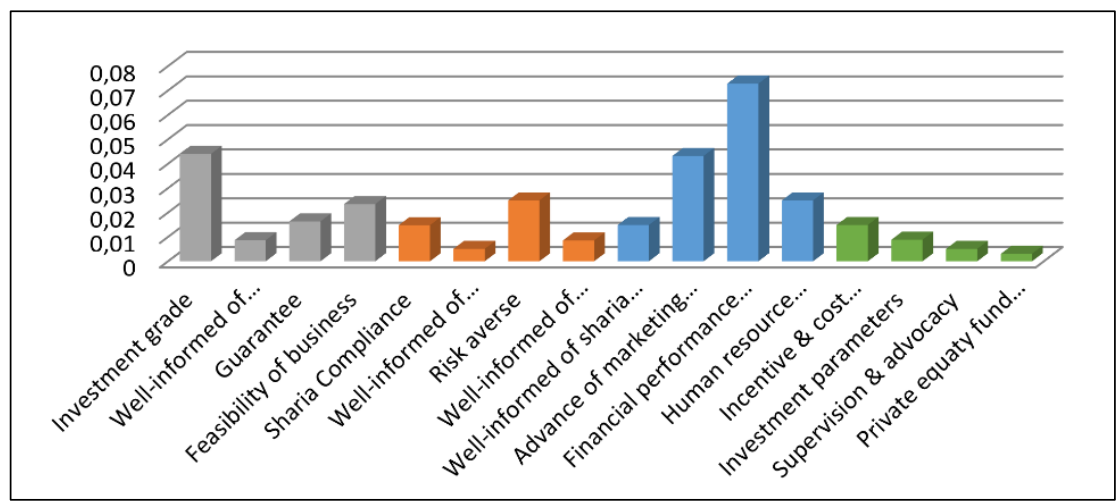

Figure 10.

Priority Level of the Overall Problem

The figure 10 indicates that the performance and experience of mutualfund/investment manager has the the highest priority level (0.073) of the problem compared to the overall problems exist in each of four main cluster problems. Following afterwards with the investment grade issue $(0,044)$ on a cluster of corporate and marketing ability (0.043) on the cluster of mutual fund/investment manager. This picture shows the consistency level of priority where there are two detailed problems of mutual fund/investment managers that become the main problem in the access limitation of Sharia Limited Participation Fund (SLPF) for MSMEs in Indonesia which also being opined by all the expert respondents.

In addition to the three very prominent issues, there are also three subsequent issues were also quite prominent but still under the priority level of those three issues. Each of these three problems, namely business feasibly which is associated with the corporate, risk averse related to the investor problem, and human resource management on the mutual fund/investment manager problems.

While various detailed issues associated with government regulations problem do not have prominet level of priority. This shows that the current government regulations having no significant problem associated with business synergy that occurs between 
mutual fund/investment manager and corporate. The highest level of priority on the issue of tax incentives and cost is considered less significant as it is in the same level of priority with the problem of mutual fund/investment manager in the issue of sharia structure knowledge.

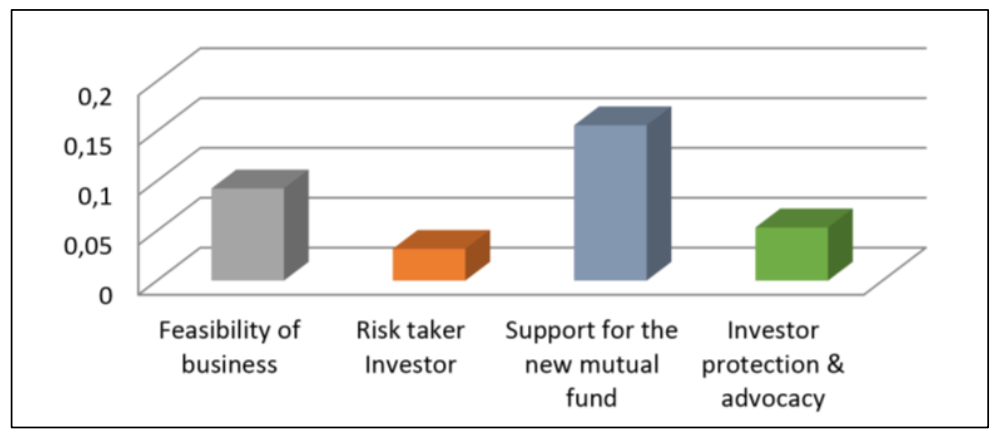

Figure 11.

Priority Level of Solution

In order to find policy solutions that can be applied in order to succeed the realization of financing for MSMEs through synergies between mutual fund/investment manager and corporate as sukuk issuer, with rater agreement 1.0, the expert respondents agree that there are at least four general issues that could be the concern any single stakeholders associated with this business model: (a) There should be fully support for the mutual fund, especially a relatively new mutual fund with no experience in the capital markets industry. (b) Corporate (venture capital) should be able to offer IMFIs and MSMEs that have good business feasibility to the mutual fund/investment manager as well as investor. These prerequisites become a concern for everyone, especially for the angel or sophisticated investor who is very sensitive to the business sector. In line with background, there should be an effort for credit rating institution to embark upon globally Sustainable Development Goals (SDGs) framework in their rating parameter. (c) The government should be able to guarantee legal certainty in the context of protection, including advocacy for investors, despite assurances from each of the sukuk issuance committed by the corporate as the issuer. (d) There is an extremely hope that investors could change their 
investment behavior paradigm, from risk averse to risk taker. Once this MSMEs are growing well, it will naturally have an impact on the potential job creation which at the same time alleviating poverty. The challenge also goes to both mutul fund/investment manager and corporate in the form of how they manage to convince the investors that choosing MSMEs as their underlying busness is not only getting profit but also has greater social impact to the society in term poverty alleviation. Figure 11 indicates that the first level of priority is goes to the problem of mutual fund/investment manager that need critically support in order to smothen the role of Islamic caiptal market to be the intermeiary institution for the growth of MSMEs in Indonesia and to realize the government policy of financial inclusion.

\section{CONCLUSION AND POLICY RECOMENDATION}

Using Analytical Network Process (ANP) approach this paper try to analyze both problem and solution associated with the Sharia Limited Participation Fund (SLPF) access for MSMEs in Indonesia. With the value of rater agreement 1.0, the research found that there are four main cluster problems which become an obstacle for the proposed model, namely: (a) the reputation of mutual fund/ investment manager; (b) investment grade rating of corporate (venture capital); (c) risk appetiate of investor as shahib al-mal; and (d) government regulation.

Policy recommendation that might become the solution, according to the value of rater agreement 1.0 is sequentially as follow, namely: (a) Fully support from government, especially for a relatively new mutual fund with no experience in the capital markets industry; (b) Corporate (venture capital) should be able to offer IMFIs and MSMEs that have good business feasibility to the mutual fund/investment manager as well as investor along with the issue of rating parameter that need to embark upon SDGs framework; (c) The government should be able to guarantee legal certainty in the context of protection, including advocacy for investors; and last but not least (d) There is an extremely hope that investors could change their investment behavior paradigm, from risk averse to risk taker. 


\section{REFERENCES}

Akerlof, G. A. (1970). The market for "lemons": Quality uncertainty and the market mechanism. The Quarterly Journal of Economics, 84(3), 488-500.

Amidzic, G., Massara, A., \& Mialou, A. (2014). Assessing countries' financial inclusion standing - A new composite index (IMF Working Paper WP/14/36).

Ascarya. (2005, n.d.). Analytic Network Process (ANP): Pendekatan baru studi kualitatif. Paper presented at internal seminar organized by Master of Accounting Program, Faculty of Economics, Trisakti University, Jakarta.

Bu-Qammaz, A. S. (2007). Risk assessment of international construction projects using the Analytic Network Process (Thesis). Middle East Technical University.

Burg, I. V., \& Rasmussen, P. N. (2007). Hedge funds and private equity: A critical analysis. Socialist Group, European Parliament.

Calvey, P., Romeo, J., \& Peterhoff, D. (2014). Towards better capital markets solutions for SME financing. Retrieved September 17, 2016, from http://www.oliverwyman.com/content/dam/oliverwyman/global/en/files/insights/financial-services/2014/July/ FINAL3_BetterCapitalMarketMechanismsSMEs.pdf

Dusuki, A. W. (2008). Banking for the poor: The role of Islamic banking in microfinance initiatives. Humanomics, 24(1), 49-66.

Fuady, M. (2006). Hukum tentang pembiayaan. Bandung: Citra Aditya Bakti.

Haddad, M. D. (2017, January 13). Perluas akses keuangan masyarakat \& UMKM, ini yang dilakukan OJK. Kompas. Retrieved from http://ekonomi.kompas.com/read/2017/01/13/225617026/ perluas.akses.keuangan.masyarakat.dan.umkm.ini.yang.dilak ukan.ojk.

Hochberg, Y. V., Ljungqvist, A., \& Lu, Y. (2007). Whom you know matters: Venture capital networks and investment performance. Journal of Finance, 62(1), 251-301. 
Indonesian Ministry of Cooperatives and SMEs. (2012). Statistik UKM [SME statistic]. Retrieved September 20, 2016, from http://www.depkop.go.id/index.php?option=com_phocadow nload\&view=category \&id=124:statistik-ukm-202\&ltemid=93

Jagongo, A. \& Mutswenje, V. S. (2014). A survey of the factors influencing investment decision: The case of individual investors at the NSE. International Journal of Humanities and Social Sciences, 4(4), 92-102.

Keuschnigg, C. (1998). Venture capital: A case for investment promotion (CEPR Discussion Paper Series No. 1887).

Kuncoro, M. (2004). Metode kuantitatif, teori dan aplikasi untuk bisnis dan ekonomi. Yogyakarta: Unit Penerbit dan Percetakan AMP YKPN.

Lembaga Pengembangan Perbankan Indonesia [LPPI]. (2015). Profil bisnis Usaha Mikro, Kecil \& Menengah (UMKM), kerjasama dengan Bank Indonesia. Retrieved September 20, 2016, from http://www.bi.go.id/id/umkm/penelitian/nasional/kajian/Docu ments/Profil\%20Bisnis\%20UMKM.pdf

Legendre, P. (2005). Species associations: The kendall coefficient of concordance revisited. Journal of Agricultural, Biological, and Environmental Statistics, 10(2), 226-245.

Memba S. F., Gakura W. R., \& Karanaja K. (2012). Venture Capital (VC): Its impact on growth of small and medium enterprises in Kenya. International Journal of Business and Social Science, 3(6), 32-38.

Organization for Economic Co-operation and Development [OECD]. (2004). Small and medium-sized enterprises in Turkey: Issues and policies. Paris: OECD Publication. Retrieved from http://www.oecd.org/dataoecd/5/1/3193273.pdf

Rakhmindyarto, \& Syaifullah. (2014). Keuangan inklusif dan pengentasan kemiskinan. Dalam buku Bunga rampai pemikiran ekonomi hijau dan keuangan inklusif. Jakarta: Bale Siasat.

Rudjito. (2003, July). Financing challenges of SME's from the policy perspective. Paper presented at the $2^{\text {nd }}$ Annual Conference of 
PECC Finance Forum on Issues and Challenges for Regional Cooperation in the Asian Pacific, Thailand, 8-9 July 2003.

Saaty, T. L. (2005). Theory and applications of the Analytic Network Process: Decision making with benefits, opportunities, costs and risk. Pittsburgh: RSW Publications.

Saaty, T. L., \& Vargas, L. G. (2006). Decision making with the Analytic Network Process: Economic, political, social and technological applications with benefits, opportunities, cost and risks. New York: Springer Science-Business Media.

Sitompul, A. (2000). Reksadana pengantar dan pengenalan umum. Bandung: PT Citra Aditya Bakti.

Sudaryanto, \& Hanim, A. (2002). Evaluasi kesiapan UKM menyongsong pasar bebas ASEAN (AFTA): Analysis perspektif dan tinjauan teoritis. Jurnal Ekonomi Akuntansi dan Manajemen, 1(2).

Sugiyono. (2005). Memahami penelitian kualitatif. Bandung: CV. Alfabeta.

Torre, A., Peria, M. M., \& Schmukler, S. (2010). Bank involvement with SMEs: Beyond relationship lending. Journal of Banking \& Finance, 34(9), 2280-2293.

UNEP Inquiry. (2016). The financial system we need. Retrieved September 16, 2016, from http://unepinquiry.org/wp-content/ uploads/2016/09/The_Financial_System_We_Need_From_Mom entum_to_Transformation.pdf

Vision of PBMT Ventura. (2016). Retrieved from http://pbmt-ventura. co.id/index.php/eng/filosofi/

World Bank. (2010). Improving access to financial services in Indonesia. Retrieved September 10, 2016, from http://documents. worldbank.org/curated/en/448491468257952510/pdf/520320v 10Revis1BLIC10a2f1summary-en.pdf

World Bank. (2014). Global financial development report 2014: Financial inclusion. 
112 The Role of Islamic Capital Market for Micro, Small, and Medium Enterprises (MSMEs) Through Synergy of Mutual Fund and Venture Capital Institution

This page is intentionally left blank 